\title{
Effect of Contraceptive Use, Parity, and Social Economic Factors on Age at Menopause at Bendo Community Health Center, Kediri, East Java
}

\author{
Estin Gita Maringga'), Rita Benya Adriani²), Ambar Mudigdo3) \\ 1) Masters Program in Public Health, Sebelas Maret University \\ 2) Health Polytechnics Program, Ministry of Health, Surakarta \\ 3) Department of Anatomical Pathology, Faculty of Medicine, Sebelas Maret
}

\begin{abstract}
Background: Menopause is the natural cessation of menstruation that usually occurs between the ages of 45 and 55. Menopause women may experience some undesirable effects, such as sleep disturbance, prone to pain, increased susceptibility to sexually transmitted disease (STD), and thinner hair. It is hypothesized that age at menopause is affected by genetic factor, as well as psychosocial factors. This study aimed to the effect of contraceptive use, parity, and social economic factors on age at menopause.

Subjects and Method: This study was an analytic observational study using case control design. The study was conducted in Bendo Village, Bendo Village, Sumberbendo Village, Pelem Village, Darungan Village, and Sambirejo Village in Community Health Center Bendo, Kediri, East Java, from 8-31 March 2017. A sample of 120 menopausal women was selected for this study by fixed disease sampling. The dependent variable was age at menopause. The independent variables were hormonal contraceptive use, duration of contraceptive use, parity, education level, and family income. The data were collected by questionnaire, and analyzed by path analysis.

Results: Menopausal age was affected by duration of hormonal contraceptive use $(b=0.29 ; \mathrm{SE}=$ $0.12 ; p=0.014)$, parity $(b=1.98 ; S E=0.49 ; p=0.001)$, and family income $(b=2.29 ; S E=0.88 ; p=$ 0.009). Duration of hormonal contraceptive use was affected by hormonal contraceptive use ( $b=$ 5.23; $\mathrm{SE}=0.57 ; \mathrm{p}=0.001)$ and parity $(\mathrm{b}=1.22 ; \mathrm{SE}=0.27 ; \mathrm{p}=0.001)$. Family income was affected by parity $(b=0.14 ; \mathrm{SE}=0.05 ; \mathrm{p}=0.002)$ and education level $(b=0.10 ; \mathrm{SE}=0.11 ; \mathrm{p}=0.361)$.

Conclusion: Menopausal age is directly affected by duration of hormonal contraceptive use, parity, and family income. Menopausal age is indirectly affected by hormonal contraceptive use, parity, and education level.
\end{abstract}

Keywords: menopausal age, hormonal contraceptive, parity, social economic factors Correspondence:

Estin Gita Maringga. Masters Program in Public Health, Sebelas Maret University, Surakarta. Email: estin.gita@gmail.com. Mobile: +6281357673430.

\section{BACKGROUND}

Menopausal period is one of the phases in a woman's life. Menopause is the cessation of female menstruation in a period of one year due to the drop in the level of estrogen hormone (Goodman, 2011). Some studies found that on average women in the USA face menopause at the age of 50 years old (Goodman, 2011).

On average, women in developing countries such as India face menopause at the age of 47.9 years old (Pathak, 2010). Based on the data from SDKI (2013), Indonesia is a developing country with the average women having menopause at the age of 49 years old.

Lately, the number of birth control (BC) acceptors around the world is on the rise. In 2015, there are about $64 \%$ of couples of reproductive age around the world use contraceptive method and $14 \%$ of them use hormonal contraceptive (United 
Nation, 2015). Based on the data from National Population and Family Planning Agency (BKKBN) shows that in 2013 there are 8,500,247 couples of reproductive age (PUS) and are new birth control acceptors and most of them use hormonal contraceptive as many as $84.39 \%$ (Kemenkes RI, 2014).

The number of couples of reproductive age in East Java in 2015 are $6,277,248$. Most of the couples are hormonal birth control acceptor by 70\% (BKKBN, 2016). Active birth control acceptor in Kediri in 2015 is $64.8 \%$ and most of the active birth control acceptors use hormonal contraceptive as many as $74.5 \%$ (Dinkes Kabupaten Kediri, 2016). According to Mulyani (2013), women who use hormonal contraceptive will be longer or older when entering menopausal age, this is due to the way the hormonal contraceptive works that is to suppress the work of the ovary.

The number of couples of reproductive age in East Java in 2015 is $6,277,248$ with the parity of $<2$ children as many as $44.16 \%$ and parity $\geq 2$ children by $55.84 \%$ (BKKBN, 2016).

The parity level of a woman will influence the age entering menopausal period, this is controlled by a hormone receptor Anti-Mullerian Hormone (AMH). The parity will stimulate the up regulation process thus causing women who had given birth more often will experience a significant rise in progesterone. The said woman will experience increasing inhibition of follicular release. The more often a woman gives birth, the longer (slower) the woman facing menopausal period (Kevenaar, 2007).

Along with the economic development of the nation, there are still many poor people in Indonesia. According to the data from statistical agency BPS East Java Province (2015), there are 17.37 million poor people in Indonesia and in East Java alone, there are 1.5 million people. The high number of poverty in Indonesia will affect the level of income and education. In general, if the level of income is rising, so will the amount and type of food (Suhardjo et al., 2010).

Besides being influenced by the income level, nutritious intake is also influenced by the level of education that could then affect the age of menopause. This is in accordance to the findings by Akahoshi et al., (2010) that stated that the higher Body Mass Index (BMI of a woman, it will be longer for them to enter the menopause period. This is related the high estrogen level on women with obesity. The fat tissue on women with BMI $\geq 30$ could synthesize estrogen. The menopausal period of a woman also needs a more serious attention. According the study by Ziberman (2015), women entering menopausal period is on fatal risk due to heart disease and stroke.

Kediri is a district in East Java with 54 elderly service post and it is one of the regions in East Java that totally has 514 elderly service post. The high number of elderly service post in Kediri, East Java is not balanced with the achievement of target to health service elderly in Kediri District which is still below target that is $63 \%$ from the initial target 65\% (Profil Kesehatan Kabupaten Kediri, 2014). From the population census result in Kediri in 2013, it was gathered that there was 763,808 inhabitants of $\geq 45$ years old.

The population census result shows that women of $\geq 45$ years old are mostly in Pare Sub-district with the number 53,805 inhabitants (BPS, 2014). From a preliminary study done in Bendo Community Health Center, Kediri District, it was gathered that there were 3,840 women in menopause. Based on the interview result, 
there were 10 women in menopause in the working area of Bendo community Health Center in Pare District with 70\% women facing menopause at a normal age range (45-54 years old) and $30 \%$ of the women facing early menopause ( $<45$ years old).

The purpose of this study was to analyze the effect of the use of hormonal contraceptive, parity, and social economy level on the menopausal age in the working area of Bendo Community Health Center, Kediri, East Java.

\begin{tabular}{l}
\hline SUBJECTS AND METHOD \\
\hline 1. Design of the Study \\
The study was an analytical observation \\
with case control design study. The study \\
was done in the working area of Bendo \\
community health center, in five villages, \\
i.e.: Bendo Village, Darungan Village, \\
Sumberbendo Village, Pelem Village, and \\
Sambirejo Village on 8-31 March 2017.
\end{tabular}

\section{Population and Sample}

The population of the study was all mothers in menopause in the working are of Bendo community health center, Kediri. The subjects of the study were 102 mothers in menopause with history of hormonal and IUD birth controls whose age were less than 60 years old, chosen using fixed disease sampling technique. The case group was menopausal mothers with history of hormonal contraceptive. The control group was menopausal mothers that had used Intra Uterine Device (IUD). The selection was done based on the birth control acceptor list from respective villages which then randomly chosen to meet the sample number needed by the researcher.

\section{Variables of the study}

There were six variables used in this study which were divided into dependent and independent variables. The dependent variable was the menopausal age. The independent variables were type of contracep- tive, duration of contraceptive use, parity, educational level, and income level.

\section{Operational Definition}

The operational definition of the type of contraceptive is women who had consciously chosen and used a contraceptive agent such as Copper T IUD and hormonal contraceptive agents (pills, injection, or implant). Duration of contraceptive use is women who had consciously chosen and used a contraceptive agent for a period of $<5$ years or $\geq 5$ years. Parity is the number of full term birth experienced by a woman without looking at the number of children (gemelli is counted as one parity) which consist of primipara and multipara.

Level of education was a structured and tiered educational pathway consisting of basic education, middle education, and high education. The low education level was categorized as <senior high school and high education was categorized as $\geq$ senior high school.

Income level was all the result of one job that is earned by the head of the family or any family member which was manifested in the form of money and goods. Low income level is $<\operatorname{Rp} 1,456,000$ and high income level is $\geq$ Rp. 1,456,0oo.

Menopausal age was the cessation of menstrual cycle which had been diagnosed after 12 months without the menstrual period which consisted of early menopause and natural menopause.

\section{Data Analysis}

The data analysis used in this study was univariate data analysis, bivariate data analysis using linear regression, and multivariate analysis using path analysis. According to Murti (2014) the steps in analyzing using path analysis are as follow:

\section{a. Model specification}

Model specification is described as the relation between the variables being studied. The studied variables are divided 
into endogenous and exogenous variables. The endogenous variable were duration of hormonal contraceptive use, income level, and menopausal age. The exogenous variable were type of hormonal contraceptive, parity, and educational level.

\section{b. Model identification}

The identification on the number of measured variables, number of endogenous variables, exogenous variables, and parameter that would be estimated. The degree of freedom (df) is also measured on this step. The result of degree of freedom (df) value is 9 meaning that it is over identified thus the path analysis could be done because $\mathrm{df} \geq 0$.

\section{c. Model compatibility}

The path analysis model that was prepared by the researcher was done based on te theory tested/checked its conformity with the best variable relation model according to SPSS program called the saturation model prepared based on the data sample collected by the researcher.

\section{d. Parameter estimation}

Cause and effect variable relation showed by the regression coefficient (b), whether it was unstandardized or standardized. Unstandardized regression coefficient showed the relation of independent and dependent variables in the orignal measuring unit. .

\section{e. Model Respecification}

If the model prepared by the researcher was not as per the data sample as showed on the saturation model and the value of regression coefficient is small nearing to nil thus statistically insignificant, therefore the path analysis model need to be redone until the model meets the data sample.

RESULT
A. Univariate Analysis
The dimension of general data charac-
teristics of the object of the study could be
seen on Table 1.
All subjects of the study was known to
not have undergone hysterectomy or
chemotherapy. The descriptive statistics of
continuous data continuous including,
duration of counter-use, parity rate, income
level, and menopausal age could be seen on
Table 2.
Table 2 showed that each variable had
only minor differences. Mean showed the
average value, while standard deviation
(SD) value showed how the data varied.
Small SD value indicated that the data is
representative.

Table 1. Characteristics of the study subjects

\begin{tabular}{clcc}
\hline Classification & & $\mathbf{N}$ & $\mathbf{\%}$ \\
\hline Hysterectomy history & 1. Yes & 0 & 0 \\
& 2. No & 102 & 100 \\
Chemotherapy history & 1. Yes & 0 & 0 \\
& 2. No & 102 & 100 \\
\hline
\end{tabular}

Table 2. Univariate analysis on the variables of the study

\begin{tabular}{|c|c|c|c|c|c|}
\hline Variables & $\mathbf{n}$ & Min. & Max. & Mean & SD \\
\hline $\begin{array}{l}\text { Duration of contraceptive use } \\
\text { (years) }\end{array}$ & 102 & 0 & 15 & 3.75 & 4.104 \\
\hline Parity & 102 & 1 & 5 & 2.77 & 1.024 \\
\hline Family income (rupiah) & 102 & 500,000 & $2,500,000$ & $1,005,392.16$ & $532,317 \cdot 32$ \\
\hline Menopausal age (year) & 102 & 40 & 55 & 47.50 & $5 \cdot 352$ \\
\hline
\end{tabular}




\section{B. Bivariate analysis}

Table 3 showed that the type of contraceptive ( $\mathrm{r}=1.71 ; \mathrm{p}=0.180)$, educational level $(\mathrm{r}=0.37 ; \mathrm{p}=0.715)$ had positive relation to the menopausal age even though it was statistically insignificant.
Duration of contraceptive use $(\mathrm{r}=$ $0.43 ; \mathrm{p}=0.011)$, parity $(\mathrm{r}=1.96 ; \mathrm{p}<0.001)$, income level $(\mathrm{r}=2.15 ; \mathrm{p}=0.020)$, had positive relation on the menopausal age and statistically significant.

Table 3. Bivariate analysis on the effect of hormonal contraceptive, level of parity, and social economy factors on the menopausal age

\begin{tabular}{lcc}
\hline Independent variables & $\mathbf{r}$ & $\mathbf{p}$ \\
\hline Contraceptive type & 1.71 & 0.180 \\
Duration of contraceptive use (years) & 0.43 & 0.011 \\
Parity & 1.96 & $<0.001$ \\
Educational level & 0.37 & 0.715 \\
Family income level /month(rupiah) & 2.15 & 0.020 \\
\hline
\end{tabular}

\section{Path Analysis}

Picture 1 showed the structural model after an estimation done by IBM SPSS AMOS 20, so as to get the value as in the picture. The indicator showed model analysis conformity as shown on Table 4. Goodness of fit measure value got the fit index CMIN of $1.44 ; \mathrm{p}=0.21>0.05 ; \mathrm{NFI}=0.96 \geq 0.90 ; \mathrm{CFI}$ $0.99 \geq 0.95 ; \quad R M S E A=0.06 \leq 0.08$. The result showed that the empirical model meets the criteria set and empirically sound.

On Table 4, it was known that the menopausal age was influenced by the duration of contraceptive use, parity, and income level. The duration of contraceptive use was influenced by the level of parity and income. Each increasing unit of duration of contraceptive use would increase menopausal age by 0.29 unit $(b=$ $0.29 ; \mathrm{SE}=0.12 ; \mathrm{p}=0.014)$.

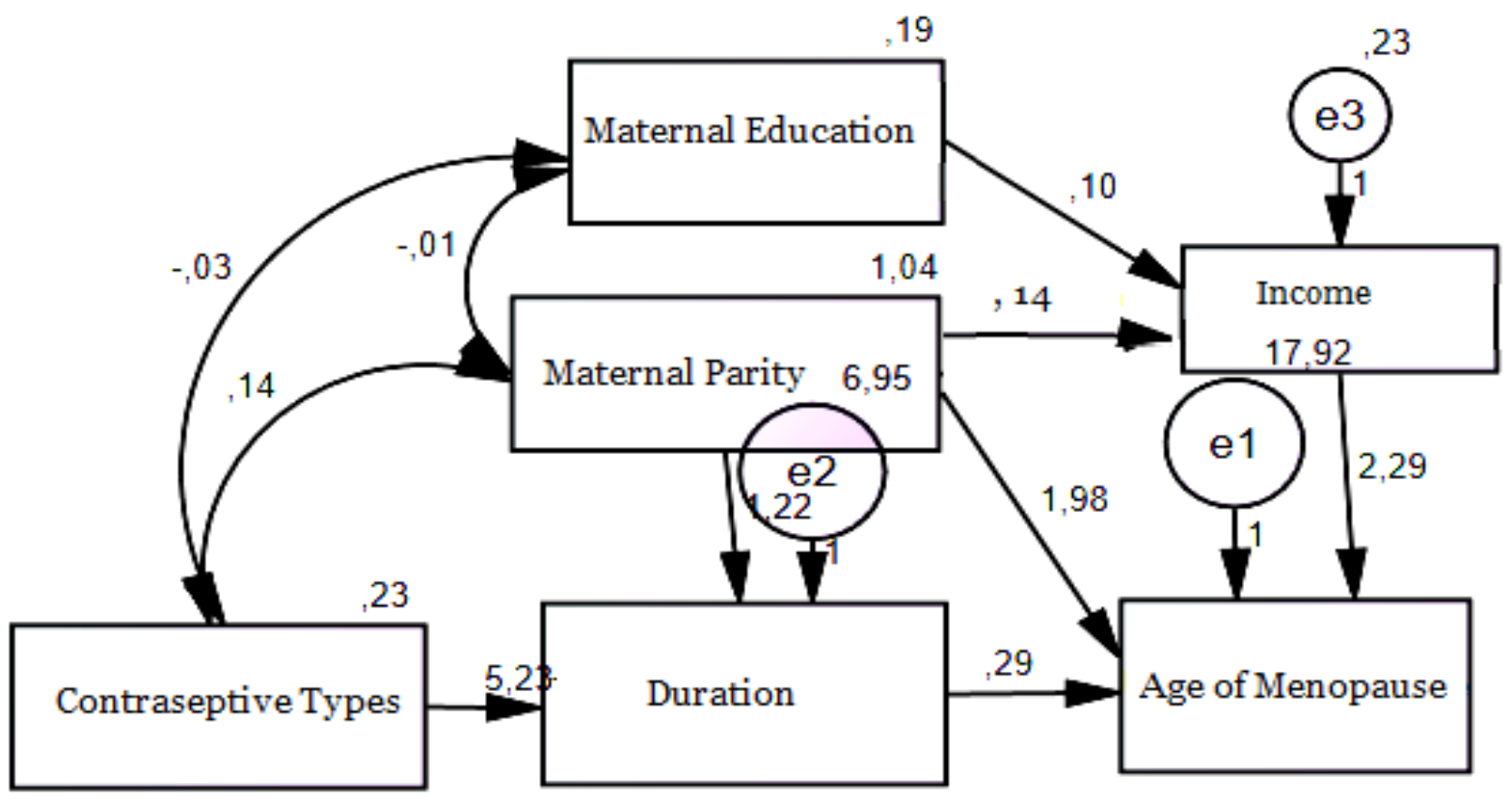

Picture 1. Path analysis with structural model 
Journal of Maternal and Child Health (2017), 2(2): 113-124

https://doi.org/10.26911/thejmch.2017.02.02.03

Tabel 4. The path analysis result on the duration of hormonal contraceptive use, parity, and social economy factor on menopausal age

\begin{tabular}{|c|c|c|c|c|c|c|}
\hline \multicolumn{2}{|l|}{ Dependent Variables } & Independent Variables & $\mathbf{b}^{*}$ & SE & $\mathbf{p}$ & $\boldsymbol{\beta}^{* *}$ \\
\hline \multicolumn{7}{|l|}{ Direct Effect } \\
\hline Menopausal age (years) & $\leftarrow$ & $\begin{array}{l}\text { Duration of hormonal } \\
\text { contraceptive use (years) }\end{array}$ & 0.29 & 0.12 & 0.014 & 0.22 \\
\hline Menopausal age (years) & $\leftarrow$ & Parity & 1.98 & 0.49 & 0.001 & 0.38 \\
\hline Menopausal age (years) & $\leftarrow$ & Income level (rupiah) & 2.29 & 0.88 & 0.009 & 0.21 \\
\hline \multicolumn{7}{|l|}{ Indirect Effect } \\
\hline $\begin{array}{l}\text { Duration of hormonal } \\
\text { contraceptive use (years) }\end{array}$ & $\leftarrow$ & $\begin{array}{l}\text { Type of hormonal } \\
\text { contraceptive }\end{array}$ & 5.23 & 0.57 & 0.001 & 0.62 \\
\hline $\begin{array}{l}\text { Duration of hormonal } \\
\text { contraceptive use (years) }\end{array}$ & $\leftarrow$ & Parity & 1.22 & 0.27 & 0.001 & 0.30 \\
\hline Income level (rupiah) & $\leftarrow$ & Educational level & 0.10 & 0.11 & 0.361 & 0.08 \\
\hline Income level (rupiah) & $\leftarrow$ & Parity & 0.14 & 0.05 & 0.002 & 0.29 \\
\hline \multicolumn{7}{|l|}{ Model Fit } \\
\hline CMIN & \multicolumn{2}{|c|}{$=1.44 \quad \mathrm{p}=0.210(\geq 0.05)$} & & & & \\
\hline$=0.98$ & \multicolumn{2}{|c|}{$=0.98(\geq 0,90)$} & & & & \\
\hline$=0.96$ & \multicolumn{2}{|c|}{$=0.96(\geq 090)$} & & & & \\
\hline$=0.99$ & \multicolumn{2}{|c|}{$=0.99(\geq 0.90)$} & & & & \\
\hline RMSEA $\quad=0.06$ & \multicolumn{2}{|c|}{$=0.06(\leq 0.08)$} & & & & \\
\hline \multicolumn{7}{|c|}{ * Unstandardized path coefficient } \\
\hline
\end{tabular}

Each increasing unit of level of parity, would increase menopausal age by 1.98 unit $(b=1.98 ; \mathrm{SE}=0.49 ; \mathrm{p}=0.001)$.

Each increasing unit of income level, would increase menopausal age by 2.29 unit $(b=2.29 ; \mathrm{SE}=0.88 ; \mathrm{p}=0.009)$

Each increasing unit of contraceptive type, would increase contraceptive use by 5.23 unit $(b=5.23 ; \mathrm{SE}=0.57 ; \mathrm{p}=0.001)$.

Each increasing unit of parity, would increase the duration of contraceptive use by 1.22 unit $(b=1.22 ; \mathrm{SE}=0.27 ; \mathrm{p}=0.001)$.

Each increasing unit of level of education, would increase level of income by 0.10 unit $(b=0.10 ; S E=0.11 ; p=0.361)$.

Each increasing unit of level of parity, would increase level of income by 0.14 unit $(b=0.14 ; \mathrm{SE}=0.05 ; \mathrm{p}=0.002)$.

\section{DISCUSSION}

\section{The effect of type of contraceptive} on menopausal age

There was a positive relation between the type of contraceptive and menopausal age even though it indirectly influence through the duration of contraceptive use.

According to Kusuma (2016) the choice of contraceptive type is related to the duration of contraceptive use.

From the result of a study by Pallikadavath et al., (2016), it shows that women who uses long term contraceptive pills has a significant relation with normal menopausal age (45-55 years old) compared to women who do never use contraceptive pills. This is supported by Stepaniak et al., (2013) that the use of hormonal contraceptive is related to longer menopausal period of a woman. Murugan et al., (2015) also mentions that the use of IUD and tubectomy will fasten a woman's menopause period.

From another study by (2014), it is gathered that women who use combined contraceptive pills on average has higher menopausal onset than those who use IUD. The menopausal onset of the users of both 
contraceptive agents is said to have differences by 1.4 years.

The study by Fitriyani (2013) shows that in fact there is no significant relationship between the use of contraceptive pills and menopausal age. The differences in the age of menopause in women is affected by many factors such as genetic. The study by Fitriyani (2013) does not study in depth about the effect of the factors on the age of menopause.

The type of contraceptive is indirectly affecting the age of menopause by the duration of use. The duration of use of the contraceptive depends on the purpose of the subject of the study whether it is to give space between births or to end fertility (Kusuma, 2016).

The duration of hormonal contraceptive use influences the menopausal age. The cause is the estrogen and progesterone content in the hormonal contraceptive affecting the body's hormonal changes. The body is continuously given the hormone so it stimulates the pituitary to not produce the estrogen and progesterone (Varney, 2006).

\section{The effect of the duration of contraceptive use on menopausal age}

There was a positive influence of the duration of hormonal contraceptive use on the menopausal age. Mulyani (2013) states that women who use long term hormonal contraceptive agent will take longer or be older entering the menopausal period. This is due to the way hormonal contraceptive works that is to suppress the work of the ovaries. Pallikadavath et al., (2016) states that women who had used long term contraceptive pills is significantly related to normal menopausal age (45-55 years old) compared to those who never used the pills before. A study done by Bentzen (2012) states that the longer the duration of contraceptive use it will lowed the level of Antral Follicle Count (AFC) and ovarian volume, and significantly raise the level of Anti Mullerian Hormone (AMH) which means that the menopause will be longer compared to women who never used hormonal contraceptive.

The study by Fitriyani (2013) shows that women who consumed contraceptive pill for five years has 0.90 times less risk of early menopause compared to women who never use contraceptive pills. The duration of hormonal contraceptive use influences the age of menopause. It is due to the estrogen and progesterone hormone content in the hormonal contraceptive that affect the hormonal change in the ovary. The body is continuously given the hormone then it stimulates the pituitary to stop producing these two hormones so that the hormones estrogen and progesterone are not produced (Varney, 2006). The longer the use od the hormonal contraceptive, the adaptation and changes in the body will also take long to happen.

\section{The effect of parity on menopausal age}

There was a positive relation between the duration of contraceptive use and menopausal age. Based on the data analysis, it is known that parity has direct effect on the age of menopause. This is in accordance to the study by Kevenaar, 2007 that the effect of parity on menopausal age is controlled by hormone receptor $\mathrm{AMH}$ or known as AMHR2 - 482 A $>$ G polymorphism. Along with the hormonal changes prior to parity, the level of progesterone becomes very high and it has been proven that it also increase the said $\mathrm{AMH}$ reception expression in the tissue. Moreover, high levels of prolactin also potentiates the up regulation effects of the AMHR2 receptor. The high level of $\mathrm{AMH}$ receptor will strengthen the initial inhibition recruitment effect process of the 
primordial follicle thus slowing down the menopausal period. The parity number will also stimulate the up regulation process, thus the the increasing number of parity will also slow down the menopausal age.

The high level of parity on the subject of the study is linked to the low level of knowledge of most the subject which mostly have basic education history was 63 subjects (61.76\%). This is in accordance to the theory by (2005) that one of the factors affecting parity is one's level of education. The higher one's level of education, the easier it would be to receive information. Mothers with high level of education have more rational way of thinking.

There was an indirect relation among parity, the menopausal age and the duration of contraceptive use. The higher the parity, the longer the use of contraceptive compared to women with low parity. Hence, the longer the menopausal period.

According to Hartanto (2005) one of the factors affecting the duration of use of the type of contraceptive chosen is parity. The longer the hormonal contraceptive used, the longer the changes and adaptation of the body (Varney, 2006). The hormonal changes causing irregular menstrual period. A negative imbalance of the hormone causing the withdrawal of the menstrual cycle, so the age of menopause will also be slow as compared to women who never use hormonal contraceptives.

There is a positive relation of parity and income level. This is due to the the assumption that the children are an economic resource and future assets, thus the presence of children is desirable in the family. High parity is linked to the family income level (Hartoyo et al., 2011).

The more the number of children, the higher the parents' effort to improve the family income level. The income level will also affect the age of menopause. Suhardjo
(2010) stated that if the income is higher, the amount and type of food will also improve. Good nutrition intake since reproductive age will influence the endocrine system in the body thus lessening the chance of early menopause.

\section{The effect of level of education on the age of menopause}

There was a link of the level of education on the income level. This was related to the interview result of most of the women of subject of the study both from the middle and high education, choosing to be a housewife.

This findings is in accordance to the theory by Bloom (1908) in Efendi and Makhfudli (2009) about the behavioral theory that the domain of behavior consist of knowledge and attitude. A woman who decided to work not only based on high education but also based on the attitude and behavior of whether a woman is willing to work or not to meet the family's needs. The income earned by the families of the subject of the study was mostly still under the minimum wages set in Kediri. This contradicts existing theoretical concept that the higher one's level of education, the better the possibility to make their economy better (Karsidi, 2008).

Even though there was not any significant relation between the level of education on income level, but there is an indirect relation on the level of education towards the menopausal age through income level. This is in accordance to the study by Shobeiri et al., (2014) that states that there is a significant relation of the level of education and menopausal age, the higher the level of education of a woman, the longer they will enter menopausal period, and vice versa. Education is one of social factors that could affect the menopause, because it determines the selection of the type of quality of food intake and 
physical activity. Good nutrition intake since the reproductive age will influence the endocrine system in the body, thus minimizing the chance of early menopause (Akahoshi et al., 2010).

This study contradicts the findings by Gold (2011) that states the level of education has a more significant relation on the age of menopause compared to the income level. The varied findings related to the social economy and menopausal age is linked to the culture that exist in each region in regards to education and work for a woman. Even though she has high education, it is not easy for a woman to decide to work to help improving the family income.

This is stated by Istibsyaroh (2004) that in every society, there are differences in the role of men and women based on the community, status, or their power. The differences in the development of gender roles in society are caused by a variety of factors, ranging from the natural environment, to the stories and myths used to solve the puzzles of gender differences.

\section{The effect of income level towards the age of menopause}

There was a direct positive relation on the income level towards the age of menopause. Income is all the revenue in the form of money that a family earns. Everyone has the right to make a living in order to earn an income to make ends meet. For low income society, they try to fulfill their daily needs, but in family with middle income level, they are more focused on meeting their basic needs such as good food, good clothes, good housing, good education, and for high income families, they fulfill all their desires including sending their children to higher level of education (Karsidi, 2008).

The conclusion is that the better the income of a person, the better the fulfillment of their basic needs related to the fulfillment of nutrition through better food.

This is supported by Suhardjo (2010) that if the level income is rising, the amount and type of of food will also get better. Good nutrition intake during the reproductive age will influence the endocrine system inside the body therefore the chance of early menopause could be minimized. This is in accordance to the study by Potsangbam et al., (2016) that states that the high level of social economy status, low parity, village living, and irregular menstrual cycle are linked to lifestyle and health in general of a woman that will also affect her menopausal age.

Based on this study, it can be concluded that the age of menopause is affected by the duration of contraceptive use, parity, and income level. The duration of contraceptive use is affected by type of contraceptive and parity. The income level is influenced by parity and level of education.

\begin{tabular}{l}
\hline REFERENCE \\
\hline Akahoshi M, Soda M, Nakashima E, \\
Tominaga T, Ichimaru S, Seto S, Yano \\
K (2010). The Effect of Body Mass \\
Index on Age at Menopause. Interna- \\
tional Journal of Obesity 26(7):961- \\
968.
\end{tabular}

Bentzen JG, Forman JL, Pinborg A, Lidegaard O, Larsen EC, Friis-Hansen L, Johannsen TH, Andersen AN (2012). Ovarian Reserve Parameters: a Comparison Between Users and Non-users of Hormonal Contraception. Reproductive BioMedicine Online, 25(6): 612-619.

BKKBN (2016). Grafik Perkembangan pencapaian KB. Diakses dari http://jatim.bkkbn.go.id/ pada tanggal 28 November 2016. 
BPS Provinsi Jawa Timur (2015). Jawa Timur dalam Angka 2015. Surabaya: BPS Provinsi Jawa Timur. ISSN: 0215 $-2193$

Dinkes Kabupaten Kediri (2016). Resume Profil Kesehatan Kabupaten Kediri. Diakses dari http://dinkes.kedirikab.go.id/?hal=dprofilkesehatan\&id= 50 pada tanggal 1 Desember 2016.

Efendi F, Makhfudli (2009). Keperawatan Kesehatan Komunitas Teori dan Praktik dalam Keperawatan. Jakarta: Salemba Medika.

Fitriyani (2013). Hubungan Penggunaan Kontrasepsi Pil dengan Usia Menopause. Jurnal Kesehatan Masyarakat Nasional 8(4).

Friedman (2005). Keperawatan Keluarga. Jakarta: EGC.

Gold EB, Syibil LC, Nancy EA, Carolyn JC, Kren A, Elaine W (2013). Factor Related to Age Natural at Menopause: Longitudinal Analysis from SWAN. American Journal of Epidemiology 178(1): 70-83.

Goodman NF, Rhoda H, Samara A, Ira K, Dwain W (2011). American Association of Clinical Endocrinologist Medical Guideline for Clinical Practice for the Diagnosis and Treatment of Menopause. AACE Menopause Guidelines Endocr Pract 17: 34-45.

Hachul H, Polesel DN, Nozoe KT, Sanchez ZM, Prado MCO, Andersen ML, Bittencourt L, Tufik S (2015). The Age of Menopause and their Associated Factors: A Cross-Sectional Population-Based Study. J Women's Health Care 5:5.

Hartanto H (2004). Keluarga Berencana dan Kontrasepsi. Jakarta: Pustaka Sinar Harapan.

Hartoyo, Melly L, Sri RM. (2011). Studi Nilai Anak, Jumlah Anak Yang Diinginkan, Dan Keikutsertaan Orang
Tua Dalam Program KB. Jur. Ilm. Kel. \& Kons, 4(1): $37-45$.

Heffner, Linda J, Schust D (2006). Sistem Reproduksi. Jakarta: Erlangga.

Karsidi R (2005). Sosiologi Pendidikan. Surakarta: LPP UMS dan UNS Pers

Kemenkes RI (2014). Situasi dan Analisis Keluarga Berencana. Jakarta Selatan: Kementrian Kesehatan Pusat Data dan Informasi

Kevenaar ME, Axel PN, Joop SE, Andre G (2007). A polymorphism in the AMH type II receptor gene is associated with age at menopause in interaction with parity. Human Reproduction 22(9): 2382-88.

Kumalasari I, Andhyantoro I (2012). Kesehatan Reproduksi untuk Mahasiswa Kebidanan dan Keperawatan. Jakarta: Salemba Medika.

Kusuma N (2016). Hubungan Antara Metode Dan Lama Pemakaian Dengan Keluhan Kesehatan Subyektif Pada Akseptor. Jurnal Berkala Epidemiologi 4 (2): 164-175.

Mulyani S (2013). Menopause. Jakarta: Nuha Medika.

Murti B (2013). Desain dan Ukuran Sampel untuk Penelitian Kuantitatif dan Kualitatif di Bidang Kesehatan. Yogyakarta: Gajah Mada University Press.

Murugan A, Vanaja (2015). Evaluation of Some Risk Factors on the Age at Menopause in South Indian Women. International Journal of Research and Review in Pharmacy and Applied Sciences 5(1):1117-1124

Pallikadavath S, Reuben Ogollah, Abhishek S, Tara D, Ann D, William S (2016). Natural Menopause among Women Below 50 years in India: A Population-Based Study. Indian J Med Res 144:366-377.

Potsangbam R, Deben SL, Ratana U, Bishwalata RK (2016). Age at Meno- 
pause and its Determinants. Annals of International Medical and Dental Research (AIMDR). ISSN (O):23952822; ISSN (P):2395-2814.

Pathak RK, Purnima P (2010). Age at Menopause and Associated Bio Social Factor of Health in Punjabi Women. Open Acces Anthropolgy Journal 3:172-180.

Profil Kesehatan Kabupaten Kediri Tahun 2014. Diakses dari http://www.depkes.go.id/resources/download/profil/ PROFIL_KAB_KOTA_2014/3506_Ja tim_Kab_Kediri_2014.pdf.

Purwoastuti E, Elisabeth S (2015). Panduan Materi Kesehatan Reproduksi dan Keluarga Berencana. Yogyakarta: Pustaka Baru Press

Rini SP (2014). Perbedaan Onset Menopause Antara Pengguna Pil Oral Kombinasi dan Akseptor Non Hormonal di kecamatan Jebres Surakarta.

Ramezani F, Mahnaz B, Roya G, Somayeh H, Kobra N, Fereidoun A (2014). Secular Trend of Menopausal Age and Related Factors Among Tehrani Women Born from 1930 to 1960; Tehran Lipid and Glucose Study. Archieve of Iranian Medicine (17)6.

Rizvanovic M, Devleta B, Zumra B, Adnan B, Gordana B, Lejla K (2013). Parity and Menarche as Risk Factors of Time of Menopause Occurance. Med Arh, 67(5):336-338.

Schoenaker, Caroline AJ, Jemma VR, Gita D (2014). Socioeconomic Position, lifestyle factors and age at natural menopause: a systematic review and meta-analyses of studies across six continents. International Jaournal of Epidemiology 43(5): 1542-1562.
SDKI (2013). Survei Demografi Kesehatan Indonesia. Jakarta

Shobeiri F, Mansour N (2014). Age at Menopause and Its Main Predictors among Iranian Women. Int J Fertil Steril. 8(3): 267-272 Steiner, Anne Z (2011). Predicting Age at Menopause: Hormonal, Familial, and Menstrual Cycle Factors to Consider. American Society for Reproductive Medicine 19(2).

Stepaniaka UK, Szafranieca R, Kubinovab S, Malyutinac A, Peaseyd H, Pikhartd A, Pajaka M, Bobakd (2013). Age at natural menopause in three Central and Eastern European urban populations: The HAPIEE study. Maturitas 75: 87-93.

Suhardjo (2010). Perencanaan Pangan dan Gizi. Jakarta: Bumi Aksara.

United Nation (2015). Trends in Contraceptive Use Worldwide. New York: Departement of Economic and Social Affairs.

Varney H (2006). Buku Ajar Asuhan Kebidanan. Jakarta: EGC

WHO (2012). Obesity and Overweight. Fact Sheet No 311 May 2012 Diakses dari http://www.who.int/mediacentre/factsheet/fs311/en/.

Ziberman, Judith M, Gustavo H, Cerezo, Sueldro MD, Perez CF, Claros NM, Vicario A (2015). Association Between Hypertention Menopause, and Cognition in Women. The Journal of Clinical Hypertention 17(12). 